Redko K. Yu., Candidate of Economic Sciences State Institution «G. M. Dobrov Institute for Scientific and Technological Potential and Science History Studies»

Kyiv, Ukraine

DOI: https://doi.org/10.30525/978-9934-26-125-1-9

\title{
THE FUEL AND ENERGY COMPLEX OF UKRAINE: CURRENT STATE AND PROSPECTS OF DEVELOPMENT
}

The fuel industry and energy are the most important sectors of the economy, which largely determine the level of economic development. In any branch of modern industry, the volume of production and the cost of production largely depends on the level of development of the fuel and energy complex. Therefore, 
economic research and analysis of the dynamics of the fuel and energy industry are of great importance for determining the correct proportions of energy development and other sectors of the economy, taking into account population growth, national income and changes in the structure of energy consumption. Since the 1960s, there has been a correlation between economic growth rates and energy consumption rates, namely the increase in GDP has been accompanied by an increase in the consumption of fuel and energy resources. In their article [3], scientists Nekrasov and Sinyak suggested several hypotheses about the development of the world energy economy in the XXI century, namely:

- Further growth of energy consumption by a level higher than in 1982. At the same time, the growth rate of energy consumption in developing countries will be much higher than in developed ones. This will lead to the fact that in the XXI century, the share of developing countries may reach half of world energy consumption.

- Significant increase in energy prices due to the depletion of cheap natural resources of fossil fuels and the introduction of new, very capital-intensive energy technologies.

- A large variety of alternative technological solutions that will meet the growing energy needs and compensate in the long run for the decline in oil and gas production.

- Intensification of the negative impact of the energy complex on the environment, at least as long as the consumption of fossil fuels will increase.

However, almost all hypotheses were not confirmed, for example, the statements of a specialist in nuclear physics and energy, President of the USSR Academy of Sciences Academician A. Alexandrov about the imminent depletion of world oil and gas resources and the demise of the oil industry 
negatively affected the industry. In the 1970s, nuclear power plants began to be built on a wide front in Ukraine [1].

Politicians play the greatest role in shaping public opinion about the exhaustion of the world's hydrocarbon potential. OPEC, as a monopolist in its supply, is interested in a special attitude to oil as an ending resource, and therefore the oil of these countries is of particular importance to the world economy. At the expense of their oil, OPEC countries are trying to control modern world economic life. From time to time, they reduce oil production, raise oil prices, and impose embargoes on its supply to countries of their choice, which leads to frequent economic shocks in the world and in some countries [1].

The same thing happens with gas. Using a valve on the pipe through which gas is supplied, monopolists impose their policies in states dependent on gas supplies [2].

However, the discovery of large deposits of oil and gas in the North, Mediterranean, and Caspian Seas, in the Atlantic Ocean off the coasts of Nigeria, Angola and Brazil, in the Gulf of Mexico indicates that oil will serve humanity for a long time. In addition, the discovery of giant accumulations of methane on the bottom of the oceans in the gas-hydrate state gives grounds to claim that hydrocarbons on Earth are almost inexhaustible [2].

The high share of imported energy resources in the structure of the fuel and energy complex reduces the level of energy security. In 2020, imported gas accounted for about 30 percent of total natural gas consumption in Ukraine. Ukraine has become 85 percent dependent on oil imports. At the same time, the share of oil products produced in the Russian Federation or from Russian raw materials (primarily in the Republic of Belarus) in the structure of imports exceeds 80 percent. In 2020, Ukraine imported more than $\$ 2.4$ billion worth of oil products from the Russian Federation 
and the Republic of Belarus. The production of different types of fuel and energy in Ukraine is shown in Figure 1.

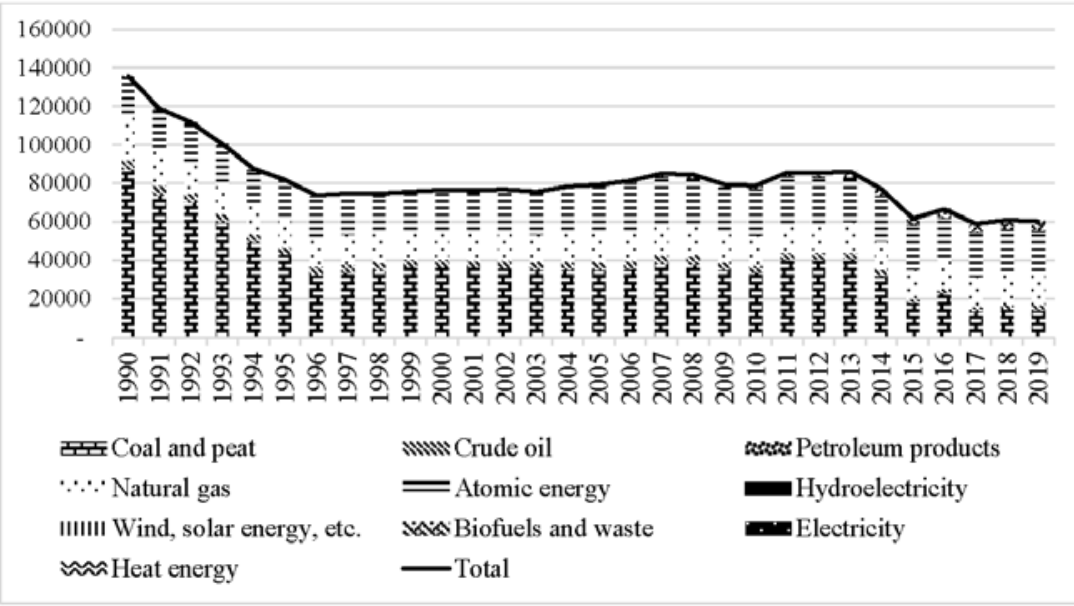

Figure 1. Production of various fuels and energy in Ukraine, 1990-2019, thousand tons of oil equivalent

From the figure, we can see that production since 1990 from 135794 decreased in 2019 to 60095 in two times. It is worth looking at the dynamics of energy production from RES (Figure 2).

We can see from Figure 2 that the production of energy from biofuels and waste from 2005 - 262 thousand tons of oil equivalent to 2019 - 3786 thousand tons of oil equivalent increased 14.5 times.

Under the Paris Agreement, Ukraine has committed itself to reducing carbon emissions by $40 \%$ from a 1990 baseline, and emissions have already been reduced by almost $64 \%$ between 1990 and 2020. The sharpest decline of $48 \%$ was due to the economic downturn after the collapse of the Soviet Union in the early 1990s, Figure 3. 


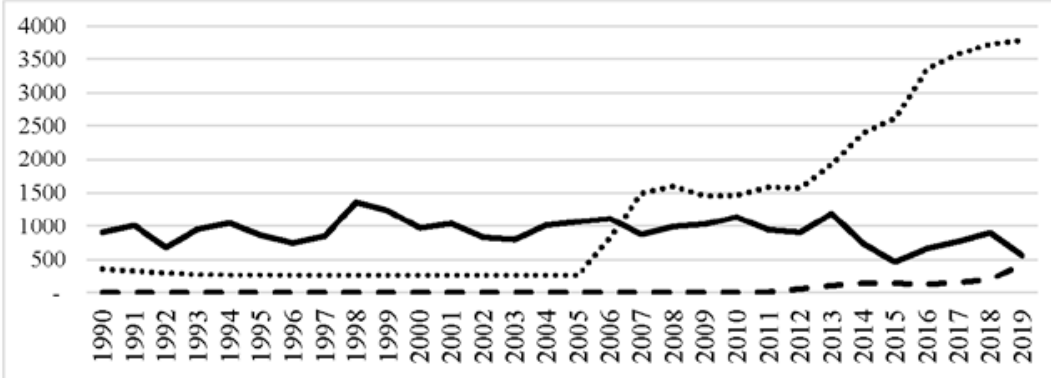

- Hydroelectricity $\quad$ - Wind, solar energy, etc. ….. Biofuels and waste

Figure 2. Energy production from RES in Ukraine, 1990-2019, thousand tons of oil equivalent

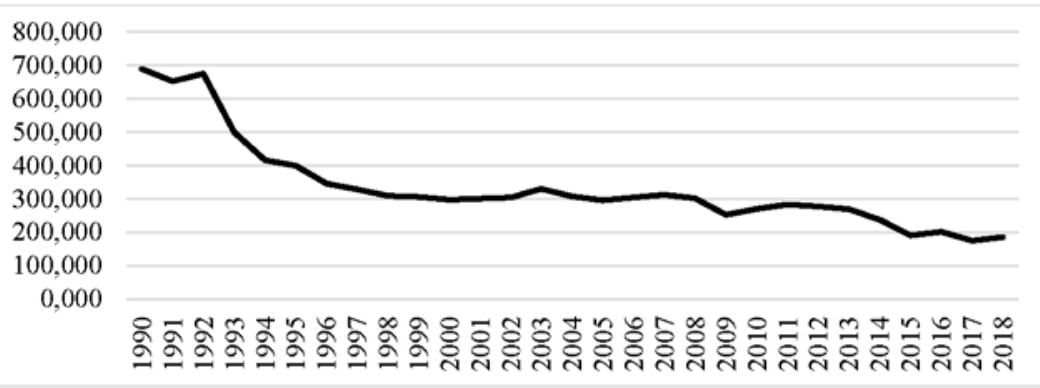

Figure 3. $\mathrm{CO}_{2}$ emissions (kg per GDP in PPP in US dollars 1990-2018) [5]

Efficiency, scale of production and consumption of energy resources determine the level of productive forces and, consequently, the development of industries. At the same time, the issue of self-sufficiency of the state with the necessary energy resources is very important. Concepts such as energy security and energy independence are becoming vital and reflected in the living standards of the people.

Unsatisfactory level of diversification of sources and routes of supply and the lack of a system of stocks of petroleum products makes Ukraine vulnerable in the event of a deliberate 
cessation of supplies of petroleum products. It is important to note that the problem of long-term supply of the national economy with natural energy raw materials requires consideration, primarily through the prism of the cost mechanism of its extraction and further processing, as well as the dynamics of demand. The issue of anthropogenic impact on the environment in the XXI century will be decisive in choosing the ways of energy development of both the world and individual countries. The challenge is to reduce the burden on the planet caused by human activities to sustainable development.

\section{References:}

1. Hozhyk P., Lukin O., Vdovychenko A., Petrovs'kyj O. (2019) A new theory of renewability, inexhaustibility and environmental friendliness of deep oil and gas resources. Available at: https://zn.ua/ukr/energy_market/ nova-teoriya-pro-vidnovlyuvanist-nevicherpnist-i-ekologichnist-glibinnihnaftogazovih-resursiv-300704_.html (accessed 01 September 2021).

2. Il'ienko B. (2021) «Gas» political geography». Available at: https://zn.ua/ukr/energy_market/hazova-politichna-heohrafija.html (accessed 02 September 2021).

3. Nekrasov A.S., Syniak Yu.V. (1982) Renewable energy sources in the perspective energy balance. Alternative energy sources: Materials of the Soviet-Italian symposium 1982. Part 1. Integrated use of alternative energy sources, Moscow, pp. 40-52.

4. State Statistics Service of Ukraine (2021). Available at: http://www.ukrstat.gov.ua/ (accessed 03 September 2021).

5. World Bank data: $\mathrm{CO}_{2}$ emissions (kg per GDP in PPP in US dollars in 2017) - Ukraine. Available at: https://data.worldbank.org/indicator/ EN.ATM.CO2E.PP.GD.KD (accessed 01 September 2021). 